DOI: 10.46340/eujem.2021.7.4.4

Oksana Dziubinska

ORCID ID: https://orcid.org/0000-0003-1478-8452

Lutsk National Technical University, Ukraine

\title{
THE MECHANISM FOR THE IMPLEMENTATION \\ OF THE CIRCULAR ECONOMY MODEL \\ IN A REGIONAL HOUSEHOLD WASTE MANAGEMENT SYSTEM
}

\author{
Оксана Дзюбинська \\ Луцький національний технічний університет
}

\section{МЕХАНІЗМ ІМПЛЕМЕНТАЦІЇ МОДЕЛІ КРУГОВОЇ ЕКОНОМІКИ В РЕГІОНАЛЬНУ СИСТЕМУ ПОВОДЖЕННЯ З ПОБУТОВИМИ ВІДХОДАМИ}

The article proposes the author's approach to assessing the transformation of the regional environment of waste management of the circular economy model. It has allowed to establish the necessity of development and application of tools and levers of development of the mechanism of use of resource potential of household waste. It is established, that the basic functioning of such mechanism is the support of hourly satisfaction of interests of participants of sphere of circulation of domestic wastes on the way of transition to model of circular economy. The mechanism of support of circular economy model in the sphere of domestic waste management includes the set of levers and tools of functional triad "interest-activity-stimulus" and allows to improve the state of use of resource potential of the region, to activate investment and innovation processes and to solve social and economic problems of local territories of the region. The structure of the mechanism systematizes its tools and levers. In the proposed mechanism the macro- and microlevers, as well as the levers of interest and the levers of stimulation are distinguished. In section of each lever the set of tools which promote its functional action is offered. The role and character of action of separate tools of participants of sphere of circulation of a household waste is revealed. It is concluded that the use of these levers and tools will improve the use of regional resource potential, intensify investment and innovation processes and solve socio-economic and environmental problems of local development in terms of household waste management. An assessment of the regional environment of waste management transformation to the model of the circular economy in terms of administrative-territorial division of Ukraine, identified positive and negative dynamics of such transformation. The reasons for the regression direction of transformation in some oblasts and insufficiently high rates of progress in other regions of Ukraine are being clarified.

Keywords: household waste, circular economy, evaluation, mechanism, levers, tools.

Постановка проблеми. В Україні у сфері регіональної економіки однією з ключових проблем сьогодення виступає неприпустимо висока концентрація побутових відходів. У деяких регіонах країни рівень накопичення побутових відходів у розрахунку на душу населення перевищує або ідентичний аналогічному показнику в окремо взятих європейських країнах. Розглядувана проблематика має пряме відношення до діяльності домогосподарств, адже на рівні промислових суб'єктів регіональної економіки проблема відходів частково вирішується в контексті реалізації політики ресурсозбереження. Відтак, це спричиняє тиск на соціально-екологічну складову регіону та суттєво стримує розвиток його економічного потенціалу із-за навантаження накопичених відходів на окремі ресурсні складові регіонального розвитку. Водночас пошук механізмів поводження 3 побутовими відходами, орієнтованих на скорочення обсягів їх захоронення, створення на їх основі 
додаткових благ, повернення матеріальних ресурсів в економічний оборот дозволить суттєво наростити потенціал економічного розвитку. В державі визначено інституційні та часові рамки в питанні управління відходами ${ }^{1}$ та, зокрема, переході на модель кругової (циклічної) економіки в поводженні з відходами. Однак, тут утворилася інституційна яма, оскільки інституційні зміни в питанні поводження з відходами позбавлені конкретно визначених механізмів їх здійснення.

Аналіз останніх досліджень і публікацій. В сучасних економічних умовах все більше міст та регіонів пов'язують свої стратегії розвитку з економічною моделлю кругової економіки, поступово відмовляючись від лінійного підходу до виробництва й споживання. На думку британських дослідників, модель кругової економіки орієнтовна на максимізацію функціонування екосистеми та підвищення добробуту людини ${ }^{2}$. При цьому всі процеси в такій моделі $\epsilon$ водночас їі результатами.

Німецький дослідник Stefan Pauliuk відмічає, що модель кругової економіки орієнтована на те, щоб перервати кореляцію економічного росту від споживання ресурсів й тим самим зменшити інтенсивність ресурсоспоживання. Водночас, перехід на модель кругової економіки сприяє появі нових економічних можливостей та створенню робочих місць. Аналізуючи прийнятий у Великій Британії стандарт BS 8001:2017 «Рамки для імплементації принципів кругової економіки в організаціях», автор наводить суть кругової економіки, як відновлювальної та регенеративної (по відношенню до біологічних ресурсів) моделі, яка орієнтована на підтримку продуктів, компонентів та матеріалів у якомога вищій цінності в будь-який момент тривалості технічних чи біологічних циклів ${ }^{3}$. У рамках імплементації моделі кругової економіки в СС були прийняті чіткі правила щодо управління відходами та визначені основні індикатори в поводженні з відходами. Так, до 2035 р. планується досягти 65\% переробки муніципальних відходів, 75\% переробки відходів упаковки, а захоронення муніципальних відходів планується скоротити до рівня $10 \%$ до 2030 р. При цьому заборонено захоронення роздільно зібраних відходів ${ }^{4}$.

Окремі дослідники в рамках програм європейського територіального співробітництва відмічають, що важлива роль у впровадженні та прискоренні переходу до кругової економіки належить місцевим владним інституціям. Останні можуть встановлювати чіткі інституційні рамки та підтримувати регіональні інціативи. При цьому слід зважати на відмінні, в розрізі регіонів та населених пунктів, прояви географічних, екологічних, соціально-економічних факторів. Тому інструменти підтримки імплементації моделі кругової економіки можуть різнитися ${ }^{5}$. Розглядаючи реалізацію моделі кругової економіки на урбаністичному рівні, польські дослідниці відмічають, що кругова економіка, при правильному залученні зацікавлених стейкхолдерів, пропонує пакет рішень, які можуть впливати на розвиток міських населених пунктів, їх самодостатність та регенеративність ${ }^{6}$. Німецькі науковиці Anna Petit-Boix та Sina Leipold, зазначають, що доступність фінансування, рівень бізнесового розвитку та обрані пріоритети впливають на реалізацію моделі кругової економіки в урбаністичному просторі. При цьому великі міста, за результатами їх дослідження, активні в реалізації інноваційних проєктів у контексті кругової економіки, особливо щодо смарт-технологій та мобільності ${ }^{7}$. 3 точки зору С. Ратнер, розробка інноваційних рішень в моделі кругової економіки сприяє переходу до нового типу економічного розвитку регіональної соціально-економічної системи, але при цьому слід ураховувати просторове розміщення продуктивних сил регіону, джерела енергії,

\footnotetext{
${ }^{1}$ Розпорядження Про схвалення Національної стратегії управління відходами в Україні до 2030 року, 2017 (Кабінет Міністрів України). Офіиійний сайт Верховної Ради Украӥни <https://zakon.rada.gov.ua/laws/show/8202017-p\#Text> (2021, липень, 28).

${ }^{2}$ Murray, A., Skene, K., Haynes, K. (2017). The Circular Economy: An Interdisciplinary Exploration of the Concept and Application in a Global Context. Journal of Business Ethics, 140 (3), 369-380.

${ }^{3}$ Pauliuk, S. (2018). Critical appraisal of the circular economy standard BS 8001:2017 and adashboard of quantitative system indicators for its implementation inorganizations. Resources, Conservation \& Recycling, 129, 81-92.

${ }^{4}$ Wielgosinski, G., Czerwinska, J., Szufa, S. (2021). Municipal Solid Waste Mass Balance as a Tool for Calculation of the Possibility of Implementing the Circular Economy Concept. Energies, 14, 1811.

${ }^{5}$ Bačová, M., Böhme, K., Guitton, M. and others (2016). Pathways to a Circular Economy in Cities and Regions, 14.

${ }^{6}$ Nowakowska, A., Grodzicka-Kowalczyk, M. (2019). Circular economy approachin revitalization: an opportunity for effective urban regeneration. Economics and Environment: Journal of the Polish Association of Environmental and Resource Economists, 4 (71), 8-20.

${ }^{7}$ Petit-Boix, A., Leipold, S. (2018). Circular economy in cities: Reviewing how environmental research aligns with local practices. Journal of Cleaner Production, 195, 1270-1281.
} 
сировини й матеріалів ${ }^{1}$. Українські науковці $Є$. Мішенін та I. Коблянська відзначають, що на регіональному рівні модель кругової економіки реалізується на основі каскадної взаємодії бізнесових структур та оптимального управління ресурсними потоками ${ }^{2}$.

Цілі статті. Метою статті $є$ виявлення передумов імплементації моделі кругової економіки в сфері поводження з побутовими відходами регіону та детермінація інструментарію механізму підтримки функціонування такої моделі.

Виклад основного матеріалу дослідження. Як показують міжнародні дослідження та практика, організування сортування, збирання, переробки та використання ресурсоцінних компонентів побутових відходів виступають ключовими елементами для забезпечення процесу раціонального кругообороту ресурсів. Інституційно українські регіони готові до впровадження моделі кругової економіки. У відповідності з директивами СС було доповнено законодавчий акт, який регламентує політику поводження з відходами в частині заборони захоронення неперероблених (необроблених) побутових відходів, встановлює правила поведінки стейкхолдерів у процесі поводження з побутовими відходами. Однак у методичному плані залишається невирішеним питання оцінювання поступу до моделі кругової економіки, особливо в регіональному контексті. Адже саме тут відбуваються основні процеси, пов'язані з генеруванням відходів, їх рухом та створюється навантаження на окремі регіональні ресурсні компоненти. На основі такої оцінки доцільно будувати інструментарій регулювання сфери поводження з побутовими відходами.

Для оцінювання поступального руху регіону до кругової економіки пропонується скористатися процедурами методики кластерного аналізу. Спочатку вихідні значення індикаторних показників будуть нормовані на основі їх поділу на показники-стимулятори та показники-дестимулятори та перетворені в безрозмірні величини.

Для цього визначаємо показники-стимулятори та показники-дестимулятори і розраховуємо відхилення:

$\mathrm{X}_{\mathrm{ij}}=\left(\mathrm{x}_{\mathrm{ij}}-\mathrm{x}_{\mathrm{imin}}\right) \div\left(\mathrm{x}_{\mathrm{imax}}-\mathrm{x}_{\mathrm{imin}}\right)-$ для стимуляторів,

$\mathrm{X}_{\mathrm{ij}}=\left(\mathrm{x}_{\mathrm{imax}}-\mathrm{x}_{\mathrm{ij}}\right) \div\left(\mathrm{x}_{\mathrm{imax}}-\mathrm{x}_{\mathrm{imin}}\right)-$ для дестимуляторів,

де $\mathrm{X}_{\mathrm{ij}}$ - нормовані безрозмірні елементи матриці вихідних даних;

$\mathrm{x}_{\mathrm{ij}}$ - фактичне значення j-го показника для i-го об'єкта дослідження;

$\mathrm{x}_{\text {imax }}, \mathrm{x}_{\text {imin }}$ - відповідно максимальне та мінімальне значення параметра по всій сукупності об'єктів дослідження.

На наступному етапі розрахуємо матрицю відстаней об’єкта за ј-им індикатором до еталонного значення. Відстань до еталону обчислюватимемо наступним чином:

$$
X=\sqrt{\sum_{j=1}^{N}\left(x_{i j}-x_{0 j}\right)^{2}}
$$

де X - відстань ознаки до точки еталону;

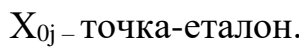

Вибір оцінюваних індикаторів відбувався на основі наступних критеріїв: мета оцінювання; об'єктивність і достовірність; універсальність. Оцінювання здійснювалося за трьома параметрами: організаційні умови для кругової економіки (включено такі показники, як: питома вага охоплення споживачів послугами збору побутових відходів, частка стихійних сміттєзвалищ), економічні умови (використовувався показник обсягу фінансування сфери поводження з відходами та показник рівня платіжної дисципліни - оплата споживачами обсягу отриманих послуг усфері поводження 3 відходами), технічні умови (враховувалися показники: обсягу перевезення відходів на пункти заготівлі вторинної сировини; обсягу перевезення відходів на сміттєпереробні підприємства; обсягу перевезення відходів до місць їх компостування; обсягу перевезення відходів на сміттєспалювальні заводи; обсягу перевезення відходів на полігони й сміттєзвалища). Таким чином, вектор-стовпець

\footnotetext{
${ }^{1}$ Ратнер, С. В. (2018). Циркулярная экономика: теоретические основы и практические приложения в области региональной экономики и управления. Инноващии, 9 (239), 29-37.

${ }^{2}$ Мишенин, Е. В., Коблянська, И. И. (2017). Перспективы и механизмы развития «циркулярной» экономики в глобальной среде. Маркетинг і менеджмент інновацій, 2, 329-343.
} 
показників, що характеризують організаційні умови матиме вигляд: $\mathrm{X}=\left(\mathrm{x}_{1}, \mathrm{x}_{2}\right)$; показниківхарактеристик економічних умов: $\mathrm{Y}=\left(\mathrm{y}_{1}, \mathrm{y}_{2}\right)$; показників технічних умов: $\mathrm{Z}=\left(\mathrm{z}_{1}, \mathrm{z}_{2}, \ldots, \mathrm{z}_{\mathrm{n}}\right)$.

В основі пропонованої методики оцінювання закладено те, що кожному оцінюваному об'єкту (регіону) відповідає точка 3 координатами, рівними інтегральним оцінкам вище зазначених груп показників. Інтегральну оцінку пропонуємо визначати як:

$$
\mathrm{I}_{\mathrm{CE}}=\left((\mathrm{X}-1)^{2}+(\mathrm{Y}-1)^{2}+(\mathrm{Z}-1)^{2}\right)^{1 / 2}
$$

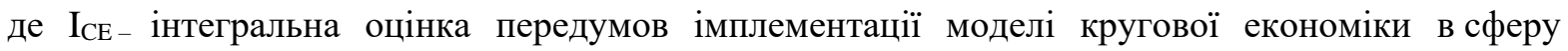
поводження з побутовими відходами регіону;

$X, Y, Z$ - інтегральна оцінка показників-характеристик організаційних, економічних та технічний умов.

Результати інтегральної оцінки відображені на рис. 1. Серед трьох оцінюваних параметрів найгірша ситуація спостерігається з технічними умовами запровадження моделі кругової економіки в регіонах України. В 2015 р. приблизно всі регіони знаходилися на одному рівні в забезпеченні технічних умов для реалізації моделі кругової економіки (дещо кращими серед інших регіонів були Київська, Рівненська та Тернопільська області). В 2019 р. ситуація суттєвим чином не поліпшилася. Найкращі показники демонструють регіони за організаційними умовами реалізації моделі кругової економіки за винятком Дніпропетровської та Житомирської областей, де цей параметр протягом періоду дослідження є гіршим за параметр економічних умов. Слід відмітити, що економічні параметри в 2019 р. у співставленні з 2015 р. значно покращилися. Полтавська область характеризується найгіршими економічними умовами для забезпечення реалізації моделі кругової економіки. В 2019 р. у співставленні з 2015 р. поступ до моделі кругової економіки спостерігався в 10 регіонах країни. Проте в жодному регіоні країни немає суттєвих успіхів упросуванні до моделі кругової економіки. В Закарпатській, Луганській, Львівській, Полтавській, Херсонській областях за аналізований період були відсутні будь-які зміни до трансформації. Регрес спостерігається в Дніпропетровській, Київській, Рівненській, Сумській, Хмельницькій та Чернівецькій областях.

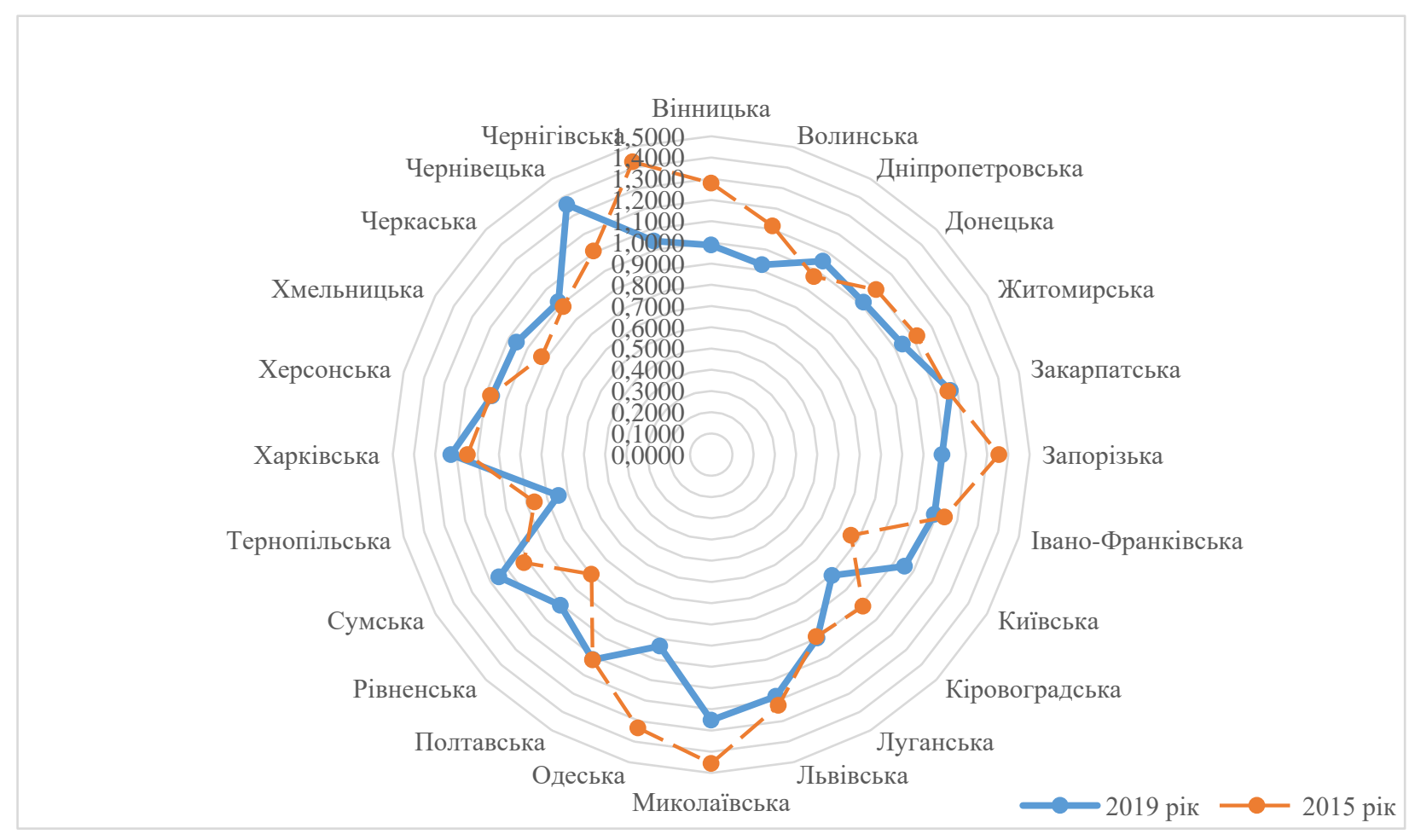

Рис. 1. Результати інтегрального оцінювання трансформації регіонального середовища поводження 3 відходами до моделі кругової економіки

Джерело: Розраховано та складено автором 
Таким чином, імплементація моделі кругової економіки в регіональну систему поводження 3 побутовими відходами гальмується та вимагає більш активних дій зі сторони регіональних владних інституцій. Останні проявляють певну пасивність у цьому питанні. Розділяємо думку професора В. Голяна, що вирішення проблеми поводження з відходами стало критерієм профпридатності не лише природоохоронних інституцій, але й інституцій місцевого самоврядування. Науковець пов'язує незадовільний стан утилізації відходів з відсутністю інтересу владних інституцій до реалізації низькодохідних, але водночас важливих проєктів. Ця байдужість проявляється й на фоні пошуку інвестицій у сферу поводження з відходами та забезпечення їх надходжень ${ }^{1}$.

Механізм підтримки імплементації моделі кругової економіки в сферу поводження 3 побутовими відходами буде функціональним, якщо базуватиметься на розвитку співпраці органів місцевого самоврядування, домогосподарств та підприємницьких структур. Конструктивність такої співпраці можлива за умови, що механізм будуватиметься на тріаді базових, 3 нашої точки зору, чинників у сфері економічних відносин - інтересу, діяльності та стимулів. Відповідно, їх слід розглядати в якості ключових важелів функціонування такого механізму.

Кожен важіль приводиться в дію рядом інструментів. Інструментами підтримки важелю інтересу виступають: внутрішні мотиви домогосподарств, які підкірплюються не лише економічною мотивацією, але й мають природу емоційного стану людини; мотиви економічної вигоди підприємницьких структур, які займаються переробкою та обробкою відходів, ремонтом тощо; стратегії та регіональні плани поводження з відходами, які виступають мотивацією роботи владних інституцій регіону й покликані забезпечити альтернативні шляхи зростання ресурсного потенціалу регіону.

Інструменти важелю діяльності покликані стимулювати процеси активної взаємодії учасників сфери поводження з відходами, виробити практики поводження з відходами, орієнтовані на ієрархію використання відходів за ключовими принципами кругової економіки. Такі інструменти за місцем їх генерування можна розділити на макро- та мезорівневі. Інструменти макрорівня передбачають застосування штрафів, податків, тарифів, імпортного мита, інвестицій та інновацій. Якщо розглядати штрафи та екологічний податок, то це інструменти, які покликані зупинити практику бездумного розміщення відходів у межах регіонального простору. В цьому ж ракурсі має задіюватися тарифний інструмент на поводження з відходами, який має становити, на наш погляд, не менше $1 \%$ середнього доходу домогосподарства регіону. Його розмір має стимулювати домогосподарства до роздільного збирання відходів. Серед податкового інструментарію слід виділити податок на додану вартість, який може застосовуватися для стимулювання виробництва продукції з вторинної сировини. Імпортне мито покликане забезпечити пільговий режим для ввезення обладнання, устаткування, що використовуватиметься в переробці, доробці відходів. Інновації та інвестиції- інструменти, що генеруються на макрорівні й покликані мобілізувати національні дослідження та технології, орієнтовані на вирішення проблеми переробки відходів, повторного використання сировини тощо при стійкій державній політиці інвестиційної підтримки сфери поводження з відходами та створення умов диверсифікації інвестиційних потоків у галузь.

Інструменти важелю діяльності мікрорівня включають технології та дизайн; маркетинг; управління якістю; матеріало- та енерговіддачу; лізинг; логістику; заробітну плату; концесійний платіж; ціну. Ці інструменти генеруються в середовищі суб'єктів господарювання, які безпосередньо зайняті виробництвом продукції як з первинної сировини, так і вторинної. Перший принцип кругової економіки полягає в тому, щоб подумати над доцільністю виробництва того чи іншого блага й коли рішення прийнято на користь виробництва - продумати технологію та дизайн продукту таким чином, щоб він легко піддавався для утилізації в майбутньому. Розвиток сектору переробки відходів відбуватиметься за умови, якщо буде подолано проблему неформальної зайнятості в ньому за рахунок офіційного працевлаштування та належного рівня заробітної плати. Управління якістю та маркетинг - взаємодоповнюючі інструменти, які мають на меті забезпечити контроль якості продукції, виробленої з вторинної сировини, що сприятиме іiі кращому просуванню на ринку. Маркетинг в круговій економіці- ключовий інструмент, який повинен спонукати споживачів звертати увагу на продукцію з відходів, навчити їх раціональній (в контексті використання ресурсів) споживчій поведінці. В цьому контексті, але по відношенню до виробників функціонують

\footnotetext{
${ }^{1}$ Голян, В. А. (2018). Інвестиції в переробку відходів: як подолати пасивність влади та бізнесу. Дзеркало тижня, 13 (359), 9.
} 
інструменти матеріало- та енерговіддачі. Вони покликані сприяти раціональному використанню ресурсів, економії первинних матеріалів та енергоресурсів. Апріорі, політика енерго- та ресурсозбереження тісно пов'язана з технологіями, що їх застосовують на виробництві. Інструменти лізингу та концесії можуть бути задіяні для створення можливостей залучення необоротних активів 3 метою формування виробничих потужностей підприємств сфери (не лише переробки, але й збирання, заготівлі ресурсоцінних комонентів відходів) для реалізації значимих проєктів у частині переробки відходів у регіонах.

Стимулюючі важелі в механізмі підтримки переходу регіональної сфери поводження з відходами на модель кругової економіки орієнтовані на спонукання до дій учасників процесу, прояву їх зацікавленості діяти в рамках принципів кругової економіки. Ці важелі включають такі інструменти, як: гранти, субсидії, циклічні публічні закупівлі, державно-приватне партнерство та інструменти спонукання до розширеної відповідальності.

Висновки 3 дослідження. Впровадження моделі кругової економіки в регіональну сферу поводження з відходами вимагає пошуку такого механізму, який би стимулював повернення ресурсів у виробничі системи, стимулював співробітництво ключових учасників. На його основі цілком можливо сформувати стійку модель кругової економіки в сфері поводження з побутовими відходами. Пропонований науково-методичний підхід до оцінювання стану трансформації регіонального середовища поводження з відходами до моделі кругової економіки довів необхідність обгрунтування важелів та інструментів механізму підтримки використання ресурсного потенціалу побутових відходів. Їх застосування покращить стан використання ресурсного потенціалу регіону, активізує інвестиційно-інноваційні процеси та вирішить соціально-економічні та екологічні проблеми розвитку локальних територій в частині поводження з побутовими відходами.

\section{References:}

1. Bačová, M., Böhme, K., Guitton, M. and others (2016). Pathways to a Circular Economy in Cities and Regions, 14. [in English].

2. Murray, A., Skene, K., Haynes, K. (2017). The Circular Economy: An Interdisciplinary Exploration of the Concept and Application in a Global Context. Journal of Business Ethics, 140 (3), 369-380. [in English].

3. Nowakowska, A., Grodzicka-Kowalczyk, M. (2019). Circular economy approachin revitalization: an opportunity for effective urban regeneration. Economics and Environment: Journal of the Polish Association of Environmental and Resource Economists, 4 (71), 8-20. [in English].

4. Pauliuk, S. (2018). Critical appraisal of the circular economy standard BS 8001:2017 and adashboard of quantitative system indicators for its implementation inorganizations. Resources, Conservation \& Recycling, 129, 81-92. [in English].

5. Petit-Boix, A., Leipold, S. (2018). Circular economy in cities: Reviewing how environmental research aligns with local practices. Journal of Cleaner Production, 195, 1270-1281. [in English].

6. Wielgosinski, G., Czerwinska, J., Szufa, S. (2021). Municipal Solid Waste Mass Balance as a Tool for Calculation of the Possibility of Implementing the Circular Economy Concept. Energies, 14, 1811. [in English].

7. Holyan, V. A. (2018). Investytsiyi v pererobku vidkhodiv: yak podolaty pasyvnist vlady ta biznesu [Investing in waste recycling: how to overcome the passivity of government and business]. Dzerkalo tyzhnya [Mirror of the week], 13 (359), 9. [in Ukrainian].

8. Mishenin, Ye. V., Koblyanska, I. I. (2017). Perspektivy i mekhanizmy razvitiya «tsirkulyarnoy» ekonomiki v globalnoy srede [Prospects and mechanisms for the development of a "circular" economy in the global environment]. Marketing i menedzhment innovatsiy [Marketing and management iHnovatsiy], 2, 329-343. [in Russian].

9. Ratner, S. V. (2018). Tsirkulyarnaya ekonomika: teoreticheskiye osnovy i prakticheskiye prilozheniya v oblasti regionalnoy ekonomiki i upravleniya [Circular Economy: Theoretical Foundations and Practical Applications in the Field of Regional Economics and Management]. Innovatsii [Innovations], 9 (239), 29-37. [in Russian].

10. Rozporyadzhennya Pro skhvalennya Natsionalnoyi stratehiyi upravlinnya vidkhodamy v Ukrayini do 2030 roku, 2017 (Kabinet Ministriv Ukrayiny) [Order on approval of the National Waste Management Strategy in Ukraine until 2030, 2017 (Cabinet of Ministers of Ukraine)]. Ofitsiynyy sayt Verkhovnoyi Rady Ukrayiny [Official site of the Verkhovna Rada of Ukraine] <https://zakon.rada.gov.ua/laws/show/820-2017-p\#Text> (2021, July, 28). [in Ukrainian]. 